\title{
Curriculum Design of Higher Education in Peace and Security Studies: Student's Perceptions of Quality
}

\author{
Kenedy Onyango Asembo \\ Email:kasembo2005@yahoo.com \\ Mutendwahothe Walter Lumadi \\ Department of Curriculum and Instructional Studies, University of South Africa \\ Lumadmw@unisa.ac.za
}

\section{Doi:10.5901/mjss.2014.v5n20p2896}

Abstract

Curriculum design remains the super-structure of an educational programme that determines its true identity and worth. But as quality issues continue to affect the delivery of higher education (HE) in the developing world due to high demand, new programmes such as peace and security studies in Africa get more affected by design constraints. In such circumstances, curriculum evaluation measures are imperative in realigning the designs to the needs of the students. In this study, data was collected from 152 students undertaking various courses in peace and security studies in Kenyan universities. The objective was to determine their perceptions of certain aspects of curriculum design of the peace and security courses they were undertaking. The results indicate design constrains with regard to practical training, content integration, credits transfer, flexibility, course duration, and timetabling. Using the service quality theory and the humanistic and social reconstructionists perspectives of curriculum design, the study recommends elimination of the design constraints in order to deliver quality peace and security studies programmes.

\section{Background}

The quest for quality teaching and learning (QTL) in peace and security studies programmes in Kenyan universities has elicited discourses regarding curriculum design in higher education (HE). Since 2000, the need to reform the country's security sector through intensified training of security personnel in order to deal with diverse security challenges has been prioritised (Republic of Kenya, 2008). In this regard, public security institutions have been cooperating with universities to achieve this goal. The HE institutions have consequently developed certificate, diploma and degree courses for the peace and security sector, especially in such areas as peace and conflict studies, criminology, security management, forensic investigations and intelligence studies, among others. This scenario has subsequently ignited discussions regarding the quality of the academic programmes offered, especially the design of the academic programmes. The debates are crucial given the recent explosion in the quest for University education in Kenya ( Gudo, Oanda and Olel, 2011) and the fact that Higher Education in Peace and Security studies (HEPPS) is still underdeveloped in African universities, particularly Kenya (Harris 2010).

Globally discourses on curriculum design in HE have focused on various approaches ranging from the need for a leaner centred curriculum (Cleveland-Innes and Emes, 2005) to a negotiated curriculum in which the student is a key decision maker (Yuksel 2010). Other scholars have recommended integration, flexibility and problem based learning (Cheng, 2007). All in all, various HE institutions have opted for various designs, among them modularisation of the curriculum to deconstruct the traditional subject-oriented designs; skills-based learning; experience-based learning; webbased learning or maintenance of the subject-based models (Bridges, 2000). No matter the design chosen, the key question in this debate is: What are the experiences of the students with the designs and what perceptions do they develop which can be useful in improving the designs for maximum learning output?

Finding answers to these questions is the core mandate of this study, nevertheless, research indicates that QTL, both in Kenyan Universities and elsewhere, is decreasing (Hoffman, 2014; Gudo, Oanda and Olel, 2011) and this suggests the need for improvements on the designs of the programmes to meet the expectations of the students. Hill, Lomas, and Mac Gregor (2003) found that students value curriculum designs that are flexible, takes account of student group experiences, make links between theory and the real world, and are up to date. Rowley (1997) further explains that 
the effectiveness of a curriculum needs to be understood from the perspective of the student. To this end, customer satisfaction in HE involves how closely the delivered curriculum has added value to the skills and competence of the students (customers) to gain better job market or career advantage. Curriculum design is therefore the link between the students's learning outcomes and the lecturer's actual delivery of the required learning. This paper therefore argues that an examination of the quality of curriculum design in Peace and Security Studies is categorical. Hence, the study set out to determine students' perception of the quality of curriculum design in the HEPSS programmes offered in Kenyan universities.

\section{Theoretical Framework}

\subsection{The Humanistic and Social Reconstructionist Conceptions of Curriculum}

The humanistic and social reconstructionist conceptions of curriculum offer insight in understanding the orientations which inform the design of quality academic programmes in HEPSS. The ideas of humanistic curriculum are centred on the development of the individual by helping them discover their real self as opposed to being shaped into a predetermined model (Mc Neil, 1996). The product of this curriculum design is not just a cognitively endowed individual but also an aesthetically and morally healthy person. The growth to the achievement of this goal implies 'learners being permitted to express, act out, experiment, make mistakes, be seen, get feedback and discover who they are' (Mc Neil, 1996:7). A well designed HEPSS curriculum should therefore enable the leaner to fully develop their individual abilities as peace and security professionals, while recognizing that they have a duty to help the citizens to equally realize their life goals. The key ingredients of the design are participation, integration, relevance, self and comprehensive student experience rather than acquisition of fragmented blocks of knowledge (Shapiro, 1987). While writing on the need to increase student autonomy in HE, Yuskel (2010: 3-4), similarly, emphasizes that quality HE is characterized by 'flexibility, inclusiveness, collaboration, authenticity and, relevance'. The curriculum is learner-centred and the role of the lecturer is to establish an emotional relationship with the students and create a supportive teaching and learning environment to enhance self learning. The lecturer also listens comprehensively to student's views, respects the students, remains ordinary and real, understands, facilitates, and acts as resource centre. Other approaches include encounter groups, meditation, game-like activities, and small group discussions (Mc Neil, 1996:9-11; Print, 1993: 51-2).

The social reconstructionist curriculum, on the other hand, emphasises the relationship between the curriculum and the social, political and economic development of the society (Print, 1993; Mc Neil, 1996). The social reconstructionist see the curriculum as an essential tool in effecting the desired social change. To them, the goals of a curriculum include determination of the range of problems faced in the society, and the key approaches for effecting the desired change (Eisner, 1979; Mc Neil, 1996). The emphasis is on confronting the leaner with the many serious problems which humanity faces be they in social studies, sciences, arts or maths, and imparting that knowledge that would help the learners to solve those problems. The instructional design involves the lecturer invoking in the student critical consciousness and making learning more liberal, while relating the subject matter to the student goals. The lecturer is to emphasize student cooperation with the community and its resources, as well as seek internship opportunities for the learners to work as equals with more experienced members of the community in social projects. The evaluation and assessment of the social reconstructionist curriculum is broad-based and includes examining student ability to articulate problems, produce solutions, reconceptualise their world outlook and take initiative towards solving a problem (Mc Neil, 1996).

\subsection{Service Quality}

This paper has conceptualized curriculum design as a service quality attribute. Boulding et al (1993) defines service quality as the gap between expectations and perceptions of a service. The eight major service quality factors identified by Wrights (1996) for HE are diversity of educational experience, access and use of facilities, personalized interaction, student quality, educational process, faculty, and professor's years of teaching experience. In another discussion, Parasuraman, Zeithaml and Berry (1985) have listed the ten determinants of service quality that can be generalized to any type of service as tangibles, reliability, responsiveness, competence, access, courtesy, communication, credibility, security and understanding. Parasuraman, Zeithaml and Berry (1990) later on summarised these determinants into five dimensions as tangible, reliability, responsiveness, assurance and empathy. A curriculum design weaves these factors together in order to come up with an educational product which should meet or exceed the expectations of the student as a customer. Consequently, the extent to which students perceive the design of these programmes as meeting their 
expectations reflect the quality of service (Zammuto et al., 1996). Hamid and Zaidatol (2004) concurs that examining the service quality attribute needs to focus on the process of delivery of instructional design. The service quality theory therefore places the HEPSS curriculum design issues within the student's lenses in order to facilitate the development of market driven and student focused programmes.

\section{Literature Review}

\subsection{Curriculum Design of HEPSS Programmes}

Minimal literature exists on the design of HEPSS curriculum with majority exploring the teaching and learning of peace and security studies in the developed world. Smith (2008) has underscored the role of vocational institutions (community colleges) in USA in offering HE in peace and security studies. The institutions have prioritized the teaching of global peace, conflict and security and have consequently adopted various curriculum design strategies, such as course infusion or development of parallel courses in order to achieve this. In addition, approaches to develop more discipline oriented content in parallel courses at the higher education level, have also been evident. Smith further notes that to overcome the burden of an inflated curriculum at the HE level, the colleges have resorted to offering credit courses and programs and reviewing courses in the social sciences and the humanities in order to accommodate these concepts. This has seen a significant majority of the colleges offering or preparing to offer courses in emergency preparedness and homeland security with both domestic and international focus. Whereas Smith's discussion accentuates the various orientations which the design of HEPSS has taken in the US, the literature is silent on the experiences of the student with these designs. This study intends to examine the perceptions of the students as a key attribute of the curriculum development process and QTL.

Jenkins (2013:178-179) discusses peace-learning as the fundamental concept which should inform the development of requisite knowledge and skills needed to build peace in order to transform conflict situations into peace situations. The concept is based on the ideas Reardon (1988) that education for social change and transformation is dependent on the process of learning, as much as on content, or even more. According to Jenkins, curriculum design of peace studies involves combining the acquisition of knowledge and skills with a transformation process in which the knowledge learnt is integrated into the knowledge and experiences of the learners. It implies contextualization and triangulation of learning in order to achieve comprehensive education. This design has been adopted by the National Peace Academy, USA. Jenkins ( 2013: 182) underscores the design characteristics as practiced as elicitation (helping the leaner to discover, through self reflection, the inherent peace building and peacemaking knowledge and skills); deliverance, or liberation (empowering the leaner towards a critique of their social positions in relations to hegemony); critical social reconstruction (cultivating a degree of critical consciousness, which drives the leaner to take some action towards social change; and; reflexion (cultivating personal awareness, introspection and triangulation as the basis for lifelong and holistic learning) futurism (preparing learners to envision and plan for the future from an informed platform) .

The author highlights the five building blocks of the curriculum as establishment of solid but flexible moral fundamentals to guide content selection, teaching methodology and curriculum innovations; the open selection of social objectives, as per the moral fundamentals to steer teaching and learning with transparent social goals; a transformative peace learning methodology with focus on generating knowledge, which may empower the leaner towards social reconstruction; curriculum delivery to adopt holistic approach in presentation of content but with bias towards social reconstruction and formation of desired human relationships; and lastly, is the outcomes of the transformative paradigm as a result of efforts to capacitate learners to pursue social transformation be they socio-economic, political, personal, or environmental. Jenkins study thus highlights the design fundamentals of a comprehensive peace studies programme. Nevertheless the need to determine students perceptions of the quality of the design as a key element of its effectiveness is categorical, hence the current study.

Kester (2013: 157) carried out a qualitative impact assessment of the peace studies programmes at UNESCO's Asia- Pacific Centre of Education for International Understanding (APCEIU) in Seoul, South Korea, and the University for Peace in San Jose, Costa Rica, which trains peace educators in the philosophy and methodology of peace education. Concerning, APCEIU, South Korea. Kester reports participant's deep satisfaction with the programme, especially on such areas as their personal and professional growth; transfer of learning; curriculum development; and planned future engagements with research in peace education. Also from the University for Peace, Costa Rica, the author found significant impact of peace studies on changing the world views of the respondents with regard to peace and participants increased interest in teaching peace education related courses, especially those focusing on environmental issues and conflict resolution. Kesters' study was therefore more on the learning effects of the students' engagement with the peace 
studies programmes. The current study however, intends to determine student's perception of the quality of the curriculum design..

In another study, Danesh (2008) carried out a comprehensive review of the basics, content, and impact of the Education for Peace (EFP) integrative curriculum in Bosnia and Herzegovina using the Integrative Theory of Peace (ITP) (Danesh 2006) to develop the Education for Peace (EFP) integrative curriculum. The ITP advances four main principles: conceptualization of peace as a product of multiple situations; recognising the desire for unity oriented beliefs as fundamental for transforming conflict situations into peaceful situations and; developing comprehensive integrated lifelong curriculum. Based on these principles, the EFP integrative curriculum drew three major concepts for its design : the principle of unity as the main motivation in human interactions; unity oriented beliefs or world views as the main structures which shape all human behaviour and; peace, as the main product of unity oriented beliefs. The design of EFP curriculum is therefore based on an 'integrative concept of development', that sees human development as a product of consciousness, which grows morally, spiritually and ethically, as one continues to understand his/her true self in relation to the society around them. The author highlights the key aspects of this curriculum as critical inquiry, emotional insight and imaginative experience. Even though EFP curriculum Model was developed for basic education in Bosnia and Herzegovina, this study acknowledges these concepts as fundamental to HE in peace studies in Kenya. However, there is still need to determine the perceptions of the students with regard to the quality of curriculum design of HEPSS in order to determine its worth among the students as customers of $\mathrm{HE}$.

In another study, Van Oord (2008) carried out a survey among students who study 'peace and conflict studies' course under the International Baccalaureate (IB) Diploma programme, programme. The study found that the curriculum design is leaner centred and pedagogical strategies of the course are more student-oriented. In particular, discussions by students are more preferred to lecturing and experiential leaning has substituted studying huge amounts of content. Lecturers therefore create leaning environments where students are free to debate on a wide range of issues without fear of victimization. They can bring conflicts from their own experiences and analyse them using the theoretical frameworks of peace they have studied. The specific design characteristics of the programme are as follows: the major concepts in the field of peace research (such as peace, conflict, violence and aggression) are offered at the introductory stage. It is thereafter followed by a discussion of the conflict from various dimensions: the intra and interpersonal, the societal and the international. The last part of the course content is on conflict transformation, where violent and non-violent protest movements, third party interventions and post-conflict management strategies are discussed in detail. The assessment of the course is by a project on an investigative study and students are expected to come up with suggestions on how to deal with discrimination, prejudice or an ongoing major conflict and achieve transformation. The findings are thereafter presented to peers.

It is important to note that during the impact assessment study of this programme students from various countries expressed that the course had a positive impact on their lives. Whereas students from conflict prone areas such as Africa, reported better understanding of themselves and their societies, those from non-conflict prone societies such as Europe were particular on their ability to learn more from student diversity and understand the genesis of global conflicts. This review underscores a situation where the quality of a HE in Peace and Security studies course has been investigated. In this study, the IB is presented as a global project and an international programme rather than a programme for a specific university or country. The current study, however, endeavoured to examine students' perception of the curriculum design of HEPSS in Kenya. Given the diverse contexts, the perceptions of the IB students cannot be taken to represent those of $\mathrm{HE}$ students in Kenya.

Elsewhere, Firer (2008) has analysed the Israeli and Palestinian peace education at Hebrew University of Jerusalem, Israel, while focusing on its key characteristic: Virtual Peace Education (VPE). The analysis underscores the VPE (the use of computers to teach peace), as the most viable means to deliver peace studies in conflict situations. Through the web based applications, 'students can link with other people at far locations to get to understand their perspectives, thereby increasing their multicultural knowledge. Firer thus accentuates the use of Information Community Technology (ICT) through VPE as an important element in the design of peace studies curriculum. During examination of the impact of VPE it was found that this design motivates the learners, helps them form relationships and enhance their global consciousness, empowers them to develop transformative initiatives meant to achieve and sustain peace in their communities. The study therefore brings out the element of ICT as a curriculum design aspect in peacebulding and peace education. The current study, however, explored the perceptions of the students with regard to the quality of curriculum design in HEPSS in Kenyan universities.

In another development, Harris (2010: 293-301) has underscored the desired objectives of the peace studies discipline as; development of a comprehensive understanding of the dynamics of the relationships involved in conflicts; enhancing critical capacity of the learners through exposure to a range of global conflict situations, assumptions, 
analyses and world views; awakening peace and conflict consciousness and their attendant consequences in the learners and; enhancing competence in peacebulding; mediation; negotiation and other non-hostility strategies for achieving lasting peace. Harris (2010: 299) further proposes the curriculum content as comprising (i) understanding of peace, violence and conflict (ii) armed and gender-based violence (iii) biological roots of violence and negative effects of violence (iv) indigenous African peacebulding mechanisms; religious resources; peace role models; (v) designing and sustaining a tradition of peace. Harris has underscored the preferred curriculum model for HE in peace studies. However, the need to determine the experiences of the students with the delivery of HEPSS in Africa is paramount in order to improve the existing curriculum models. The current study aimed to bridge the gap by examining student's perception of the quality of the existing HEPSS designs in universities in Kenya.

In another analysis of security education in the US, Adolf (2010) underscores the design challenges facing HE in security studies, especially in the areas of teaching, research and development of HE security programmes. These include, among others the traditional alignment of the security studies programmes to the criminal justice programmes offered to public law enforcement officers and lack of accreditation of security education programmes. The author notes that there is no form of accreditation to validate the content of the programmes, making it difficult to verify whether the existing college security programs are of standard quality. Adolft also decries delivery of instruction by security lecturers with vast security experience but limited academic research focus, hence resulting into a security manager with practical skills but limited theoretical grounding. Yet the essence of $\mathrm{HE}$ institution is to blend practice with theory through teaching and research. These challenges are based on Adolf's discussion of private security industry but are however key in enriching the discourse of the public security sector. A comprehensive understanding of these dynamics would benefit more from an investigation of the perceptions of the students with regard to these design challenges.

In another discussion, Hill (2007: 134) notes that the rapid pace at which security is growing as a profession worldwide put increased demand on HE to develop relevant courses to match the required skills in the industry. Hill argues that security professionals perform a wide range of duties for a number of socio-economic sectors including financial sector, estate development, cultural properties, sports, government, hospitals, manufacturing, ICT, investigations, hotels, security engineering and design, security equipment sales and services; transportation and utilities. It follows therefore that even though the specialization and orientation of security professionals may be unique, the general skills needed to carry out the basic security functions remain similar. Therefore security studies programmes must be comprehensive enough to address the unique needs of security professionals in a dynamic setting.

Hill further notes that the work of a security professional goes beyond traditional security roles and is more of preventive than reactive. Hence, students pursuing security studies should be prepared to provide security leadership roles to their organizations and such develop an understanding of administrative, technical, supervisory, and managerial competencies alongside the traditional security skills. This requires the curriculum design to provide for students to pursue coursework in security management, business studies, law, counter terrorism, incident and disaster management, personnel management and information management. Hill has thus highlighted the orientation which HE in security studies is taking in the US. Nevertheless there is still need to know the perceptions of the students undertaking these courses with regard to the quality of the curriculum designs in order to develop quality programmes or improve the existing ones.

In further review of the available literature on security studies, Spracher (2010), in his study of HE in Intelligence studies in the US equally emphasizes that the main goal of intelligence studies should be to produce credible intelligence analysts, who can critically examine a problem and come up with workable solutions, as well as efficient managers and professionals, who are able to collect, collate, process, disseminate and keep the entire intelligence cycle vibrant. The author found that the high explosion of intelligence studies in the US has not dissuaded many intelligence professionals from their traditional orientation, perhaps due to the fact that a large number of the colleges have not been addressing the core competencies developed by ODNI under the new intelligence community orientation in the US, since to curriculum developers were ignorant of them. The competencies are engagement and collaboration, critical thinking, personal leadership and integrity, accountability for results, technical expertise, and communication. Spracher's survey emphasizes the need for a transformative curriculum design that would change the conservative orientation of the Intelligence community towards a more pragmatic approach to handling security issues. While this revelation is important in realigning the curriculum developers to the needs of stakeholders, the need for the design to be enriched further by student's own perceptions as customers of HE, is imperative. The current study intends to fill this gap.

\section{Methodology}

The study adopted a descriptive survey design. Data was collected through random sampling by use of questionnaires 
from a total of 152 finalist and pre-finalist students undertaking diploma and undergraduate courses in peace and security academic programmes in five universities in Kenya (one private and four public). The courses were international relations, military science, peace and conflict studies, criminology, criminal justice, security management, police science and forensic investigations. The questionnaire was a modified Service Performance (SERVPERF) instrument using a five-point Likert rating scale, which had the following scoring points: 5-strongly agree; 4-agree, 3- somewhat agree; 2disagree, and 1- strongly disagree. The interviews involved both Focused Group Discussions (FGDs) and In-depth interviews. The data was analysed quantitatively by use of Statistical Package for Social Sciences (SPSS) Version 17.0.

\section{Findings}

Table 1 presents data on student' perception of the curriculum design of the peace and security studies programme. It was measured through a total of eight variables (items 1-9) which comprised the place of student research; adequacy of content; interrelatedness of material; difficulty level of content; flexibility of syllabus; quality and design of practical training and; course duration.

Table 1: Frequency, Percentage, Mean Score and Standard Deviation of Student's Perception of the Design of the Programmes in Peace and Security Studies in Kenyan Universities

\begin{tabular}{|c|c|c|c|c|c|c|c|c|c|c|}
\hline \multirow{2}{*}{$\mathrm{S} / \mathrm{N}$} & \multirow{2}{*}{$\begin{array}{l}\text { Quality Attribute } \\
\text { Programme Design }\end{array}$} & \multirow{2}{*}{ Total } & \multicolumn{6}{|c|}{ Frequency and Percentage (\%) } & \multirow{2}{*}{$\begin{array}{l}\text { Mean } \\
\text { Score } \\
\end{array}$} & \multirow{2}{*}{ SD } \\
\hline & & & Low & $\%$ & Mod & $\%$ & High & $\%$ & & \\
\hline 1. 101 & $\begin{array}{l}\text { The courses in this program encourage students to do } \\
\text { research to prove certain facts. }\end{array}$ & 152 & 10 & 6.6 & 24 & 15.8 & 118 & 77.6 & 2.7105 & 0.58266 \\
\hline 2. 102 & The content of the courses in this program is adequate. & 152 & 10 & 6.6 & 28 & 18.4 & 114 & 75.0 & 2.6842 & 0.59156 \\
\hline 3. 103 & $\begin{array}{l}\text { The degree of inter relatedness of the material covered in this } \\
\text { program is consistently high. }\end{array}$ & 152 & 9 & 5.9 & 34 & 22.4 & 109 & 71.7 & 2.6579 & 0.58802 \\
\hline 4. 104 & $\begin{array}{l}\text { The difficulty level of the content of the courses in this } \\
\text { program is suitable to my level of ability. }\end{array}$ & 152 & 10 & 6.6 & 33 & 21.7 & 109 & 71.7 & 2.6513 & 0.60088 \\
\hline 05 & The time available for this course is adequate & 152 & 17 & 11.2 & 21 & 13.8 & 114 & 75.0 & 2.6382 & 0.67647 \\
\hline 6. 106 & $\begin{array}{l}\text { The course syllabus is flexible and accommodates students } \\
\text { opinion }\end{array}$ & 152 & 14 & 9.2 & 34 & 22.4 & 104 & 68.4 & 2.5921 & 0.65463 \\
\hline 107 & The quality of practical content in the program is good & 152 & 19 & 12.5 & 25 & 16.4 & 108 & 71.1 & 2.5855 & 0.70424 \\
\hline 8. 108 & $\begin{array}{l}\text { The practical training in this program is well planned and } \\
\text { beneficial }\end{array}$ & 152 & 25 & 16.4 & 29 & 19.1 & 98 & 64.5 & 2.4803 & 0.76314 \\
\hline & Overall Mean Score & & & & & & & & 2.6231 & 0.43204 \\
\hline
\end{tabular}

Key: Low= Lower Agreement; Mod = Moderate Agreement; High = Higher Agreement; SD= Standard Deviation

The table indicates that the highest mean (Mean= 2.7105) is for item No. 1 focusing on the importance given to research. The mean scores however tend to reduce for items 2-8, (Means= 2.6842, 2.6579, 2.6513, 2.6382, 2.5921, 2.5855 and 2.4803 , respectively) focusing on adequacy, course duration, coherence, difficulty level of the content, flexibility of the syllabus and practical training. This suggests that even though students highly perceive research undertakings as an integral part of the programme, they have moderate perceptions of the other aspects of course design. In particular, the data suggest that the students perceive the programmes as rigid and less effective in delivering practical training. The overall mean score of 2.6231 with SD of 0.43204 suggests student's lower perceptions of the design of peace and security academic programmes.

Data collected from the interviews and FGDs, however, highlighted concerns among the students with the design of the peace and security studies programmes. The concerns were on timetabling, practical training, credit transfer and content integration.

On time tabling, student's expressed the need for a flexible and comprehensive timetable that is responsive to their status as day scholars. One student of armed conflict and peace studies had this to say:

The university should ensure that during time tabling, full information concerning all the course units offered in the department and when they are offered, is availed to the students in time so that students can make an informed choice concerning which ones to register for. Students have been experiencing problems with some units which are only offered at certain times, since it is hard to plan when to take them. This interferes with students' learning. The department should also try as much as possible to at least ensure that all units are offered within the same geographical location, especially in the main campus, to avoid inconveniences that arise due to distance problems. Lessons that are 


\begin{abstract}
scheduled very early in the morning or late in the evening should stop because not all students are boarding in the college.

The students further decried the low regard for practical training by the institutions. One degree student of disaster management, had this to say:

The university should however facilitate more laboratory facilities to enable students conduct their practical activities more easily. Similarly, internships and practical lessons need to be offered promptly and should be organized according ones' area of specialization and not just for the general course.
\end{abstract}

On curriculum integration and credit transfer, the students called for revision of the repetitive sections of the syllabus and introduction of new content as the courses progressed to advanced years. They also expressed their desire to be allowed to transfer some credits, especially when one proceeds from a diploma to a degree course in the same university. This would shorten the duration one takes to complete a degree course, as duplication of content would be minimised. Other students expressed the need for concentrations, especially in the criminal justice courses.

\title{
6. Discussions
}

The high mean score for item 1 (Mean $=2.7105$ ) on the role of research in the peace and security studies programmes emphasize the high regard given to research in the courses. This however, contrasts with Adolf (2010) who notes that one of the challenges facing higher education in security studies, is lack of adequate research focusing on security. The current study, however, did not conduct further inquiry into the details of the research undertakings, but the students reported carrying out research on topics of their choice, but which are related to the courses they are undertaking. If this trend continues, then Adolf concurs that it is a journey towards the right direction for HEPSS.

The low mean score for item 2 'course syllabus is flexible and accommodates students opinion' (Mean=2.5921) coupled with students concerns about the rigidity and inflexibility of the programmes, suggests the need for the institutions to involve students more in curriculum development. To this end, Yuskel (2010) has advocated for a 'negotiated curriculum', which increases the students' role in curriculum decision making, and consequently enhances the ideals of a humanistic curriculum. The low perceptions of practical training as indicated in items 7- 8 ( Means=2.5855 and 2.4803, respectively ) downplays the emphasis of Jenkins (2013) on a transformative peace learning methodology with focus on cultivating a degree of critical consciousness, which drives the leaner to take some action towards social change. Similarly, it contradicts Mc Neil (1996:7) who stresses the importance of practical training, especially internship opportunities, where learners work as equals with more experienced members of the community in social projects. It is in this environment where learners are permitted to express, act out, experiment, make mistakes, be seen, get feedback and discover who they are'. This further implies that the strong emphasis on research (indicated in item 1) with minimal practical training, may not deliver quality training. The gap further implies that an examination of student ability to articulate problems, produce solutions, reconceptualise their world outlook and take initiative towards solving a problem (Mc Neil, 1996), is not possible.

The overall moderate mean score of $2.6231(\mathrm{SD}=0.43204)$ is an indication that the design of the programmes is not appealing enough to meet the expectations of students as customers of HEPSS. This finding echoes the concerns of a number of studies that QTL in Kenyan Universities is decreasing due to the escalating student population which constrain the ability of the teaching staff to give their students full attention (Gudo, Oanda and Olel, 2011). It is also in agreement with Hoffman (2014) who decries the deteriorating nature of University teaching. This has made many lecturers avoid the non- mandatory engagement with students. The student's desire for a flexible and comprehensive timetable that is responsive to their status as day scholars in agreement with Hill, Lomas, and Mac Gregor (2003) who found that students valued a curriculum that was flexible, took account of the student group experiences, and was up to date. Similarly, the students call for revision of the repetitive sections of the syllabus and introduction of new content as the courses progressed to advanced years is in agreement with Harris (2010: 293-301) who underscores the need for HEPSS to enhance critical capacity of the learners through exposure to a range of global conflict situations, assumptions, analyses and world views. The introduction of new content with enable HEPSS to focus on critical inquiry, emotional insight and imaginative experience, which according to Danesh (2008) are fundamental design attributes.

\section{Conclusion}

The study therefore concludes that students of HEPSS do hold moderate perceptions of the quality of the design of HEPSS curriculum. Even though they highly perceive the programmes as research-oriented, their low perceptions of the practical aspects, content integration, time-table flexibility, credit transfer and course duration, indicate the curriculum 
design is not student oriented and hence less effective in meeting their needs. Design constraints are therefore real in the attempts by Kenya universities to deliver a humanistic and social reconstructionist HEPSS curriculum. These constraints are likely to hamper the ability of HEPSS to deliver quality HE to students as customers.

\section{Recommendations}

The study therefore recommends to the HE institutions to improve practical training, content integration, flexibility, credit transfer, and course duration in order to strengthen the design of HEPSS curriculum. There is need for more student involvement in decision making with regard to the highlighted design issues. More research should also be focused on examining the various design patterns in HEPSS in Kenyan universities and their effectiveness in meeting the expectations of students as customers of HE.

\section{References}

Adolf D (2010). Security Studies and Higher Education, Journal of Applied Security Research, 6:1, 124-134,

Boulding W., A Karla, R staelin and V. Zeithmal (1993). A dynamic process model of service quality: from expectations to behavioural intentions. Journal of Marketing Research 30: 727.

Bridges, D. (2000). Back to the future: The higher education curriculum in the 21st century. Cambridge Journal of Education; Mar 2000; $30,1$.

Cheng, K. (2007). The Curriculum Design in Universities from the Perspective of Providers Education; Summer 127, 4.

Cleveland-Innes, M. and Emes, C (2005) Principles of Learner-centered Curriculum: Responding to the Call for Change in Higher Education Claudia, The Canadian Journal of Higher Education; 2005; 35, 4.

Danesh H.B. (2008) The Education for Peace integrative curriculum: concepts, contents and efficacy, Journal of Peace Education, 5:2, $157-17$.

Eisner, E. (1979). The Educational Imagination: On the design and evaluation of school programs. New York: Macmillan.

Firer, R (2008). Virtual peace education, Journal of Peace Education, 5:2, 193-207

Gudo, C.O., Olel, M. A., and Oanda I O (2011b). University Expansion in Kenya and Issues of Quality Education: Challenges and Opportunities International Journal of Business and Social Science Vol. 2 No. 20; November 2011

Hamid J. A. and Zaidatol A. P (2004). Students' Perception of the Quality of Teaching and Learning in Business Studies Programs. Pertanika Journal of Social Sciences and Hummanities 12(1): 71-86 (2004) .

Harris G. (2010). Studying Conflict, violence and peace in African universities High Educ (2010) 59:293-301.

Hill J (2007) Security Management at the University of Denver University College, Journal of Security Education, 2:4, 133-147

Hill, Y, I. Lomas and.J. Mac Gregor (2003). Students' perceptions of quality in higher education. Quality Assurance in Education 11(1): 15-20.

Hoffman, E.M. (2014) Faculty and Student Relationships: Context Matters, College Teaching, 62:1, 13-19, DOI: 10.1080/ 87567555.2013.817379

Jenkins T (2013). The transformative imperative: the National Peace Academy as an emergent framework for comprehensive peace education, Journal of Peace Education, 10:2, 172-196.

Kenya Police (2004) National Task Force on Police Reforms. Nairobi, Government Printer.

Kester K (2013). Peace education: an impact assessment of a case study of UNESCO-APCEIU and the University for Peace, Journal of Peace Education, 10:2, 157-171.

Mc Neil, J. (1996). Curriculum: A Comprehensive Introduction ( Fifth Edition ). Los Angeles. HarperCollins College Publishers.

Parasuraman, A., Zeithaml, V. and Berry, L.L (1990). Delivering Quality Service: Balancing Customer Perceptions and Expectations. New York. The Free Press.

Parasuraman, A., Zeithaml, V.A. and Berry, L.L. (1985) "A conceptual model of service quality and its implications for future research", Journal of Marketing, 49(Autumn), pp. 41-50.

Print, M. (1993). Curriculum Development and Design. St. Leonards, NSW Australia, Allen and Unwin

Reardon, B (1988). Comprehensive Peace Education: Educating for Global Responsibility. New York, : Teachers College, Columbia University Press.

Republic of Kenya (2008). Vision 2030. Nairobi. Government Printer.

Rowley, J. (1997). Beyond service quality dimensions in higher education and towards a service contract. Quality Assurance in Education 5(1): 714.

Shapiro, S.B (1987). 'The instructional values of Humanistic Educators: An expanded empirical analysis' Journal of Humanistic Education and Development 24 No. 3 155-70.

Smith D.J (2008) Global peace, conflict and security: approaches taken by American community colleges, Journal of Peace Education, 5:1, 63-78, DOI:10.1080/17400200701859395

Spracher, W (2010). 'Intelligence Education: A broader domain than Intelligence studies'. A Conference Paper adapted from a Doctoral Dissertation entitled 'National Security Intelligence Professional Education: A Map of U.S. Civilian University Programs and Competencies'. Unpublished Dissertation, George Washington University. This paper is part of the Conference Papers under 
Custody of International Studies Association, US.

Van Oord L (2008). Peace education: an International Baccalaureate perspective, Journal of Peace Education, 5:1, 49-62.

Wrights (1996) Quality Factors in higher education: the students' viewpoint. College Student Journal 30 June: 269-27l.

Yuksel, Ulku (2010). Integrating Curriculum: Developing Student Autonomy in Learning in Higher Education, Journal of College Teaching and Learning; Aug 2010; 7, 8

Zammuto, R., Keaveney, S., O'Connor, E. (1996). Rethinking student services: assessing and improving service quality. Journal of Marketing in Higher Education, 7(1), pp. 45-70. 